\title{
A Study of Serum Magnesium Level in Type 2 Diabetes Mellitus Patients
}

\author{
M. Manonmani' ${ }^{1}$ K. Manimekalai2 ${ }^{*}$ \\ ${ }^{1}$ Government Sivagangai Medical College, Sivagangai, Tamilnadu, India \\ ${ }^{2}$ Department of Pharmacology, Mahatma Gandhi Medical College and Research Institute (SBVU), Pondicherry, India \\ Email: *dr.manonmani2011@gmail.com
}

How to cite this paper: Manonmani, M. and Manimekalai, K. (2018) A Study of Serum Magnesium Level in Type 2 Diabetes Mellitus Patients. Journal of Diabetes Mellitus, 8, 20-26.

https://doi.org/10.4236/jdm.2018.82003

Received: February 2, 2018

Accepted: May 14, 2018

Published: May 17, 2018

Copyright (๑) 2018 by authors and Scientific Research Publishing Inc. This work is licensed under the Creative Commons Attribution International License (CC BY 4.0).

http://creativecommons.org/licenses/by/4.0/

\section{c) (i) Open Access}

\begin{abstract}
Background: Type 2 Diabetes Mellitus (DM) is characterized by insulin resistance in peripheral tissues together with impaired secretion of insulin. DM is the most common metabolic disorder with magnesium deficiency, having $25 \%$ to $39 \%$ prevalence. Osmotic diuresis accounts for a portion of the magnesium loss. Plasma magnesium and intracellular magnesium concentrations are tightly regulated by several factors. Insulin is the most important factor. Insulin may modulate the shift of magnesium from extracellular to intracellular space. In the present study we try to estimate serum magnesium in type 2 $\mathrm{DM}$ and also to find the association with duration of T2DM. Materials and Methods: The study will be conducted in Thanjavur Medical College, Thanjavur. 25 diabetes patients and 25 healthy volunteers were included in the present study. Age group of the study subjects were between 35 and 67 years. Approximately $3 \mathrm{ml}$ of fasting serum samples and $1 \mathrm{ml}$ of whole blood samples will be collected in Clinical Chemistry laboratory for the estimation of fasting glucose (GOD-POD method), 2-hour post glucose levels and $\mathrm{HbA1c}$ (HPLC method), Lipids profile was estimated by IFCC approved clinical chemistry analyzer (fully automated). Results: There was statistically significant difference in BMI, fasting blood sugar (FBS), Post Prandial Blood Sugar (PPBS), lipid profile and $\mathrm{Mg}$ (in DM groups). HbA1c $(P<0.001)$ levels were statistically significance with DM patients. Serum Mg levels were correlated showed negative correlation except High Density Lipoprotein (HDL) had positive correlation. The Serum Mg levels are significantly decreased along with the duration of the diabetes. Conclusion: Hypomagnesemia is seen in type 2 DM and inverse correlation with duration of the diabetes also. Supplementation of Magnesium can prevent chronic complications related to diabetes mellitus.
\end{abstract}




\section{Keywords}

Diabetes Mellitus, $\mathrm{Mg}, \mathrm{HbA}_{1} \mathrm{c}$, Metformin

\section{Introduction}

Type 2 diabetes mellitus (type $2 \mathrm{DM}$ ) is a non-autoimmune, complex, heterogenous and polygenic metabolic disease in which body fails to produce enough insulin, characterized by abnormal glucose homeostasis [1]. It is the predominant form of Diabetes, accounting for $90 \%$ cases globally, is a worldwide health crisis, WHO predicts an incidence of 300 million by 2025 [2]. As per International Diabetes Federation (IDF) the number of diabetes is said to raise from 40.9 million to 69.9 million by the year 2025 in India. Type 2 DM is characterized by insulin resistance in peripheral tissues together with impaired secretion of insulin. DM is the most common metabolic disorder with magnesium deficiency, having $25 \%$ to $39 \%$ prevalence. Osmotic diuresis accounts for a portion of the magnesium loss [3].

Pathophysiology of Type $2 \mathrm{DM}$ is due to 1 ) resistance to the action of insulin in peripheral tissues particularly muscle and fat but also liver 2) defective insulin secretion, particularly in response to a glucose stimulus 3) increased glucose production by the liver. Glucose itself is a crucial part of cellular ion homeostasis, increasing intracellular calcium and decreasing intracellular magnesium [4]. Prevalence of hypomagnesemia in DM is about 65\% [5].

Magnesium is the fourth abundant mineral in our body and most abundant intracellular cation [6]. Magnesium is involved in many carbohydrate oxidation, enzymatic reactions, glucose transport mechanism, insulin secretion and in binding activity [7] [8]. Approximately 50\% of total body magnesium is present in bones. Other $50 \%$ is found predominantly inside the cells of tissues and organs. Only $1 \%$ of magnesium is found in blood. The homeostasis of magnesium depends upon the amount of ingestion, efficiency of absorption and excretion from intestine and kidney.

Magnesium acts as a cofactor in more than 320 enzymatic reactions involving energy metabolism and nucleic acid synthesis. It is involved in several processes including hormone receptor binding and gating of calcium channels, transmembrane ion flux, regulation of adenylate cyclase, muscle contraction and neuronal activity, control of vascular tone, cardiac excitability and neurotransmitter release. Magnesium increases the body's ability to utilize sodium, potassium, calcium, phosphorus, vitamin B complex, vitamin C, E. Intracellular magnesium is located within the mitochondria apparently because magnesium binds strongly with ATP. More metabolically active cell is the higher in its magnesium content. Plasma magnesium and intracellular magnesium concentrations are tightly regulated by several factors. Insulin is the most important factor. Insulin may modulate the shift of magnesium from extracellular to intracellular space. 
In the present study we try to estimate serum magnesium in type $2 \mathrm{DM}$ and also to find the association with duration of T2DM.

\section{Materials and Methods}

The present study was conducted at Thanjavur Medical College Hospital, Thanjavur in the 2013. 50 clinically diagnosed Type 2 DM patients ( 25 males and 25 females) were included in study group and 50 healthy individuals were included in the control group ( 25 males and 25 females) with Age ranged from $35-67$ Years. Sample size of the study was selected based on the prevalence of Type 2 DM. Type 2 DM with complications, chronic kidney disease, cardiovascular diseases, drugs like (thiazide diuretics, steroids) alcoholics, and diarrhea were excluded from the study.

$3 \mathrm{ml}$ of fasting and $2 \mathrm{ml}$ of postprandial venous blood sample taken under aseptic precaution. Fasting and postprandial blood glucose, lipid profile (Total Cholesterol, Triglyceride, HDL, LDL-calculated and VLDL-calculated) were estimated by using IFCC approved method. Serum magnesium is estimated by spectrophotometric method using xylidyl blue 1 [9]. Xylidyl blue 1 forms a red complex in alkaline solution with magnesium. The absorbance at $520 \mathrm{~nm}$ of there xylidyl blue 1 magnesium complex is proportional to the concentration of magnesium in the sample. Informed consents were obtained from all patients and healthy volunteers before they entered the study. Student $t$ test done to compare BMI, fasting blood glucose and postprandial glucose levels between control and study groups. Pearson coefficient correlation between Serum Magnesium and lipid profile. One way ANOVA was performed duration T2DM and serum magnesium in study groups.

\section{Results}

The primary objective of the study was to compare the levels of serum Mg between T2DM and control groups, for that we had recurred 50 T2DM patients and 50 healthy volunteers after appropriate screening. Analysis of the report showed that there was a statistically significant decrease in the level of $\mathrm{Mg}$ in T2DM when compared with control group ("p" < 0.001) which is depicted in Table 1. Other anthropometric and biochemical parameter like BMI, FBS, PPBS and Lipid profile also presented with statistical significance.

Secondary objective was to find the association of $\mathrm{Mg}$ levels with biochemical parameter and duration of the T2DM. As in the literature we also found that there is negative correlation between $\mathrm{Mg}$ levels and all biochemical parameter, except HDL which showed a positive correlation with serum Mg levels in T2DM as in Table 2. Duration of T2DM and serum Mg levels had negative correlation, as year progress serum magnesium level come down Table 3 and Figure 1.

\section{Discussion}

Magnesium is an intracellular cation plays a role in cellular metabolism. Hypomagnesemia in DM has been reported in many studies [10] [11] [12]. In our 
Table 1. Mean bmi, biochemical parameter of control and study groups.

\begin{tabular}{cccc}
\hline Variables & Control & Study & Statistical inference \\
\hline BMI & $22.09 \pm 1.48$ & $25.49 \pm 1.49$ & $\mathrm{p}<0.000^{\star}$ \\
S. FBG $(\mathrm{mg} / \mathrm{dl})$ & $92.92 \pm 10.30$ & $132.64 \pm 17.51$ & $\mathrm{p}<0.000^{*}$ \\
S.PPBG $(\mathrm{mg} / \mathrm{dl})$ & $125.20 \pm 6.09$ & $244.10 \pm 69.02$ & $\mathrm{p}<0.000^{*}$ \\
S.Mg $(\mathrm{mg} / \mathrm{dl})$ & $2.10 \pm 0.21$ & $1.61 \pm 0.37$ & $\mathrm{p}<0.000^{*}$ \\
\hline
\end{tabular}

${ }^{*} \mathrm{P}<0.05$ is statistically significant.

Table 2. Pearson correlation between S. magnesium, S. Fbg, S. Ppbg, In study group.

\begin{tabular}{ccc}
\hline \multicolumn{2}{c}{ PARAMETERS } & “" value \\
\hline & FBG $(\mathrm{mg} / \mathrm{dl})$ & $-0.6190^{*}$ \\
& PPBG $(\mathrm{mg} / \mathrm{dl})$ & $-0.7379^{*}$ \\
& TC $(\mathrm{mg} / \mathrm{dl})$ & $-0.6114^{*}$ \\
MAGNESIUM $(\mathrm{mg} / \mathrm{dl})$ Vs & TGL $(\mathrm{mg} / \mathrm{dl})$ & $-0.5363^{*}$ \\
& HDL $(\mathrm{mg} / \mathrm{dl})$ & $0.6660^{*}$ \\
& VLDL $(\mathrm{mg} / \mathrm{dl})$ & $-0.5363^{*}$ \\
& LDL U/L & $-0.6243^{*}$ \\
\hline
\end{tabular}

Table 3. Duration wise serum mean magnesium levels in study group.

\begin{tabular}{cccc}
\hline Duration $(\mathrm{yrs})$ & Mean & S.D & "p" value \\
\hline$<3$ yrs $(\mathrm{n}=10)$ & 1.5360 & 0.1670 & \\
$4-6$ yrs $(\mathrm{n}=21)$ & 1.2621 & 0.2846 & $\mathrm{p}=0.0001^{\star}$ \\
$7-9$ yrs $(\mathrm{n}=10)$ & 1.044 & 0.1194 & \\
$>10$ yrs $(\mathrm{n}=9)$ & 1.015 & 0.1208 & \\
\hline
\end{tabular}

${ }^{*} \mathrm{P}<0.05$ is statistically significant.

\section{Mean $\mathrm{Mg}(\mathrm{mg} / \mathrm{dl})$}

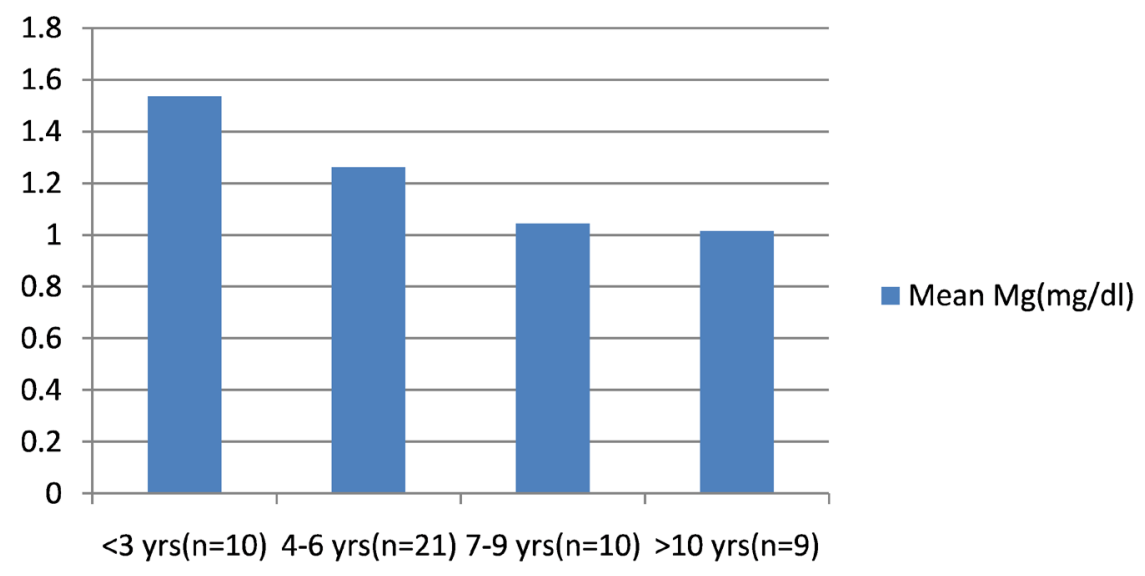

Figure 1. Mean serum magnesium levels in relation to duration of type $2 \mathrm{dm}$. 
study there is significant hypomagnesemia in Type 2 DM $(\mathrm{p}=0.0001<0.05)$. Similar findings have been reported in studies done in serum magnesium status in Type 2 DM. [13] [14] There is negative correlation between serum magnesium levels with fasting and postprandial blood glucose level. This has been reported in a study done by Diwan, et al., Tripath, et al., Naila Masood, et al. Diabetes Mellitus is one of most common causes of magnesium deficiency although is related to poor metabolic control [15].

In type $2 \mathrm{DM}$ patients, hypomagnesemia can be a consequence or a cause of increased insulin resistance. The reason for high prevalence may be attributed to increased urinary loss (osmotic dieresis), low dietary intake or impaired absorption of magnesium compared to healthy individuals [16]. Intracellular magnesium plays a key role in regulating insulin action, insulin-mediated glucose uptake and vascular tone Reduced intracellular magnesium concentrations result in defective tyrosine kinase activity, impede phosphorus bond dependent reactions of the many enzymes related to glucose metabolism, impair insulin receptor function through increased microviscosity of the plasma membrane and thus decrease insulin sensitivity and worsening of insulin resistance in diabetic patients [17].

Hypomagnesemia is associated with low high density lipoprotein, and increased triglyceride, very low density lipoprotein and low density lipoprotein levels. Insulin can increase free magnesium entry into the cell in insulin resistance, insulin-induced entry of magnesium is impaired [18]. The influence of magnesium on cell membrane ATPase activity and consequently on intracellular sodium, calcium, potassium metabolism may also play a role in diabetic complication. Hypomagnesemia when it is chronic, it increases the risk of macro and microvascular complications of DM [19]. Low levels of magnesium promote endothelial cell dysfunction and thrombogenesis by increasing platelet aggregation and vascular complication. Magnesium has been shown to inhibit platelet activation by inhibiting thromboxane A2 \& interfering with the IIb-IIa receptor complex formation [20]. The influence of magnesium on cell membrane ATPase activity, consequently on intracellular $\mathrm{Ca}^{2+}, \mathrm{Na}^{+}, \mathrm{K}^{+}$metabolism may also play a role in diabetic complications. Hypomagnesemia when it is chronic, increases the risk of macro and microvascular complications of DM [15] [19].

Magnesium exists only in very small amounts in blood and serum magnesium is not always precise a indicator of intracellular magnesium content, intracellular concentration measurement would have enabled better assessment of magnesium status in diabetes mellitus.

\section{Conclusion}

To conclude, Hypomagnesemia is seen in type $2 \mathrm{DM}$ and inverse correlation between magnesium level and fasting and postprandial blood glucose levels. Periodic monitoring of Magnesium concentration and Magnesium supplementation can prevent chronic complications related to diabetes mellitus. 


\section{Limitations of the Study}

Along with Magnesium, uric acid and thyroid profile estimations can be included for the study in future.

\section{References}

[1] Chrisopter, J. and Hupfeld, C., Courtney, H. and Olefsky, J.M. (2010) Type 2 Diabetes Mellitus: Etiology, Pathogenesis and Natural History. In: Jameson, J.L. and De Groot, L.J., Eds., Endocrinology Adult and Paediatric, Volume 1, 6th Edition, Saunders Elseveir, Philadelphia, 765.

[2] Buse, J.B., Polonsky, K.S. and Charles (2007) Type2 Diabetes Mellitus. In: Kronenberg, H.M., Melmed, S., et al., Eds., Williams Texbook of Endorinology, 11th Edition, Saunders Elsevier Publication, Philadelphia, 1329.

[3] Mohan, V., Sandeep, S., Deepa, R., et al. (2007) Epidemiology of Type 2 Diabetes: Indian Scenario. Indian Journal of Medical Research, 125, 217-230.

[4] Hussain, F., Arif Khan, M., Sheikh, M.A., et al. (2009) Trace Elements Status in Type Diabetes. Bangaladesh Journal of Medical Science, 8, No. 3.

[5] Shaikh, M.K., Devranjani, B.R. and Soomal, A.A. (2011) Hypomagnesemia in Patients with Diabetes Mellitus. World Applied Science Journal, 12, 1803-1806,

[6] Hans, C.P., Sialy, R. and Bansal, D.D. (2002) Magnesium Deficiency and Diabetes Mellitus, Review Article. Current Science, 83, No. 12.

[7] Masood, N., Baloch, G.H., Ghori, R.A., et al. (2009) Serum and Magnesium in Type 2 Diabetic Patients. Journal of the College of Physician Surgeons Pakistan, 19, 483-486.

[8] Meludu, S.C. and Adeniyi, F.A.A. (2001) Effect of Magnesium Supplementation or Plasma Glucose in Patients with Diabetes Mellitus. African Journal of Biomedical Research, 4, 111-113.

[9] Endres, D.B. and Rude, R.K. (2006) Mineral and Bone Metabolism. In: Burtis, C.A., Ashwood, E.R. and Bruns, D.E., Eds., Tiez Text Book of Clinical and Molecular Diagnostios, 4th Edition, Saunders Publication, , Philadelphia, 1911.

[10] Seyoum, B., Siraj, E.S., Sanez, C. and Abdulkadir, J. (2008) Hypomagnesemia in Ethiopians with Diabetes Mellitus. Ethnicity Disease, 18, 147-150.

[11] Kareem, I., Jawed, S.A., Bardapurkar, J.S. and Patil, V.P. (2004) Study of Magnesium, Glycosylated Hemoglobin and Lipid Profile in Diabetic Reinopathy. Indian Journal of Biochemistry, 19, 124-127. https://doi.org/10.1007/BF02894270

[12] Chambers, E.C., Heshka, S., et al. (2006) Serum Magnesium and Type 2 Diabetes in African Americans and Hispanics: A New York Cohort. Journal of the American College of Nutrition, 25, 509-513. https://doi.org/10.1080/07315724.2006.10719566

[13] Khan, L.A., Alam, A.M.S., Ali, L., et al. (1999) Serum and Urinary Magnesium in Young Diabetic Subjects in Bangladesh. The American Journal of Clinical Nutrition, 6, 70-73. https://doi.org/10.1093/ajcn/69.1.70

[14] Walti, M.K., Immermann, M.B.Z., et al. (2003) Low Plasma Magnesium Type 2 Diabetes. Swiss Medical Weekly, 133, 289-292.

[15] Khemoaml, S.S. and Karira, A. (2011) Magnesium Deficiency in Heart Failure Patients with Diabetes Mellitus. Journal of the Pakistan Medical Association, 61, 901.

[16] Sales, C.H. and Pedrosa Lde, F. (2006) Magnesium Diabetes Mellitus: Their Relation. Clinical Nutrition, 25, 554-562. https://doi.org/10.1016/j.clnu.2006.03.003 
[17] Linda Kao, W.H., Folsom, A.R., Neito, J., et al. (1999) Serum and Dietary Magnesium and the Risk for Type 2 Diabetes Mellitus, The Atherosclerosis Risk in Communities Study. Archives of Internal Medicine, 159, 2151-2159.

https://doi.org/10.1001/archinte.159.18.2151

[18] Resnick, L.M., Altura, B.T., Gupta, R.K., et al. (1993) Intracellular and Extracellular Magnesium Depletion in Type 2 Diabetes Mellitus. Diabetologin, 36, 767-770. https://doi.org/10.1007/BF00401149

[19] Longstreet, D.A., Health, D.L., et al. (2007) Correlations Suggest Low Magnesium May Lead to High Rates of Type 2 Diabetes in Indigenous Australians? Rural and Remote Health, 7, 843.

[20] Tong, G.M. and Rude, R.K. (2005) Magnesium Deficiency in Critical Illness. Journal of Intensive Care Medicine, 20, 3-17. https://doi.org/10.1177/0885066604271539 